\title{
Untold story of Deccan Traps: Role of silicate Liquid Immiscibility
}

\author{
Payel Dey, Jyotisankar Ray* and Indu Ray \\ Department of Geology, University of Calcutta, India
}

Received: 阱 January 31, 2018; Published: 制 February 12, 2018

*Corresponding author: Jyotisankar Ray, Department of Geology , University of Calcutta, 35, Ballygunge Circular Road, Kolkata700019, India

\section{Mini Review}

Role of liquid immiscibility has immense importance in petro genesis of basaltic magmas. Roedder, Weiblen $[1,2]$ postulated that high silica and high iron glasses of the lunar basaltic rocks have widespread petro genetic significance. In lunar basalts, generally, the globules of dark brown glass appear to have composition equivalent to Pyroxene + Iron ore. On the contrary, it is significant that Washington [3] initially recognized that the residual glass in the Deccan Trap basalts should be composition corresponding to a mixture of augite and magnetite. The role of liquid immiscibility in basaltic magmas had been graphically depicted by Roedder [4] in terms of $\mathrm{SiO}_{2}-(\mathrm{FeO}+\mathrm{MgO}+\mathrm{CaO})-\left(\mathrm{K}_{2} \mathrm{O}+\mathrm{Na}_{2} \mathrm{O}+\mathrm{Al}_{2} \mathrm{O}_{3}\right)$ diagram; characteristically the liquid immiscibility field in Roedder's ternary plot assumes an elongated elliptical geometry relatively away from SiO2-rich corner. The compositions of terrestrial basalts like Deccan Trap [3] Palisade diabase sill [5] etc. fall close to the demarcated liquid immiscibility field of Roedder [4]. The samples of lunar basalt obtained from Apollo 11 and 12 expeditions were also plotted in the ternary plot proposed by Roedder [4].

However, plots of those lunar rocks are slightly away (from $\mathrm{SiO}_{2}$ ) from the designated immiscibility field. It is an interesting point to note that basaltic magma parental to the Skaergaard layered igneous complex [6] (representative of Large Igneous Province) also plots close to the immiscibility field boundary with minor staggering. Again from Duluth complex, Minnesota (a representative of Large Igneous Province) Ripley [7] documented existence of sulfide and Fe - Ti -P rich liquid immiscibility, which occurred in continuum. Liquid immiscibility has been described elsewhere (related to plume controlled rift magmatic activity as for example in Panzhihua SW China) where two stage immiscible liquid separations was found to be a valid mechanism with contrasting liquid composition: one with extremely $\mathrm{Fe}$ - Ti rich gabbroic composition and the other one is normal syenitic composition. De [8] aptly discussed the role of liquid immiscibility in cases of lunar basalts and Deccan Trap basalts. De [8] was of the opinion that the role of liquid immiscibility during Deccan Trap magma differentiation is a widespread petro genetic process analogous to mechanism suffered by lunar basalts [9].

However, during last three decades unfortunately the role of liquid immiscibility in Deccan petro genesis has not been properly evaluated with adequate emphasis as they had demanded to. Such liquid immiscibility- based studies were adequately thrashed upon with field and phase chemical studies in other Flood basalt province of the world. As for example in Siberian Traps, magma chamber scale liquid immiscibility has been elucidated by Kamenetsky et al. [10]. These natural immiscible melts as found in Siberian Traps correspond extremely well to the conjugate liquids experimentally produced in common basaltic compositions at less than $1025^{\circ} \mathrm{C}$. In recent years, however, role of distinct presence of liquid immiscibility has been envisaged from part of Eastern Deccan Province [11]. According to Ganguly et al. [11], the parts of the Eastern Deccan Volcanic Province (based on mineralogical, petrological and geochemical signature) presence of three distinct flows is clearly discernable, which are controlled by fractional crystallization of phenocrystal phases, closely followed by liquid immiscibility. In fact, Ganguly et al. [11] have critically mapped distinct domains of immiscible liquid pods (with geochemical grounds) in each of the three lava flows from parts of Eastern Deccan. Therefore the challenge of the day is to identify the potential sectors within Deccan Traps showing prominent role of liquid immiscibility during magma generation and extrusion. Such proposed future studies will definitely unravel intricacies and variation in the style of liquid immiscibility in Deccan petro genesis.

\section{References}

1. Roedder E, Weiblen PW (1970) Silicate liquid immiscibility in lunar magmas, evidenced by melt inclusions in lunar rocks. Science 167(3918): 641-644.

2. Roedder E, Weiblen PW (1970) Silicate liquid immiscibility found in the lunar rocks. Geotimes 15: 10-13. 
3. Washington HS (1922) Deccan traps and other plateau basalts. Bulletin of the Geological Society of America 33(4): 765-804.

4. Roedder E (1951) Low temperature liquid immiscibility in the system $\mathrm{K}_{2} \mathrm{O}-\mathrm{FeO}-\mathrm{A}_{2} \mathrm{O}_{3}-\mathrm{SiO}_{2}$. American Mineralogist 36: 282-286.

5. Turner FJ,Verhoogen J (1960) Igneous and metamorphic petrology (2nd eds.), New York, USA.

6. Wager LR, Brown GM (1967) Layered igneous intrusions: WH Freeman and Company and Publisher. San Francisco, USA.

7. Ripley EM (1994) a comparison of apatite-bearing $\mathrm{Cu}$-Ni sulfide mineralization and transgressive apatite-oxide rocks: A possible link between Duluth Complex magmatism and massif-type anorthosites labs. Geological Society of America Abstracts with Programs 26: A312.
8. De A (1974) Silicate Liquid Immiscibility in the Deccan Trapsand Its Petrogenetic Significance. Geological Society of America Bulletin 85: 471-474.

9. Roedder E, Weiblen PW (1971) Petrology of silicate melt inclusions, Apollo 11 and 12, and terrestrial equivalents. Second Lunar Science Conference Proceedings 1: 507-528.

10. Kamenetsky VS, Charlier B, Zhitova L, Sharygin V, Davidson P, et al. (2013) Magma chamber-scale liquid immiscibility in the Siberian Traps represented by melt pools in native iron. Geology 41(10): 1091-1094.

11. Ganguly S, Ray J, Koeberl C, Saha A, Thöni M, et al. (2014) Geochemistry and petro genesis of lava flows around Linga, Chhindwara area in the Eastern Deccan Volcanic Province (EDVP). Journal of Asian Earth Sciences 91: 174-193.
(C) (P) This work is licensed under Creative

To Submit Your Article Click Here:

Submit Article

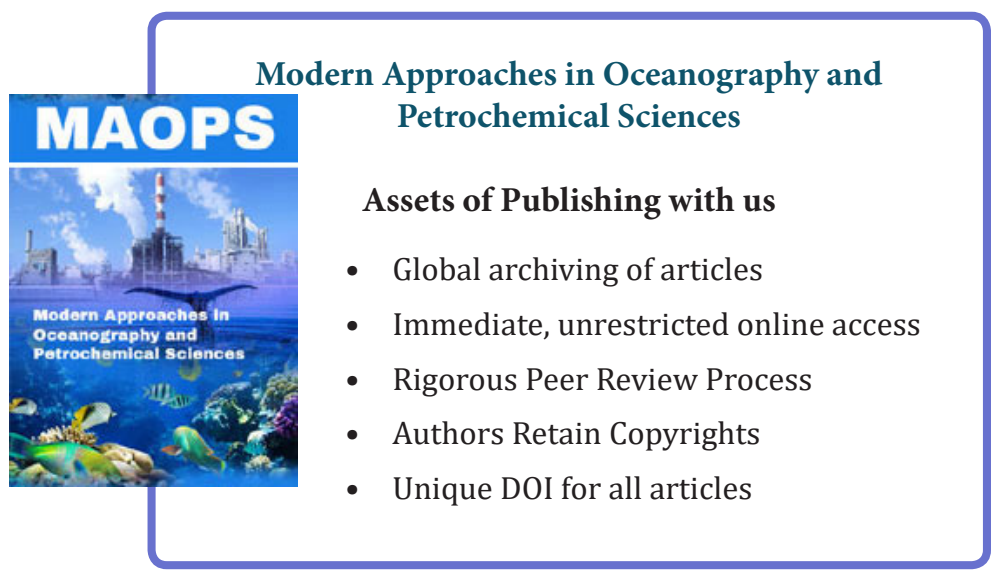

